\title{
Digital Marketing in E-Business
}

\author{
Nisha M. Ajani \\ Assistant Professor, NSM Degree \& Junior College, Vile Parle, Mumbai
}

\begin{abstract}
A look back on 2020, A year that made a huge difference. no place else has remarkable and unforeseen development happening as inside the computerized and online business sectors, which have exploded during the Covid emergency. In the midst of easing back monetary movement, Covid has prompted a flood in internet business and sped up advanced change.
\end{abstract}

With the change and evolution of contemporary technologies, small and medium businesses do everything they'll to stay up, which may be said to be true for the remainder of human society.

Businesses are either changing their business model to an internet one, or briefing up existing marketing efforts with digital marketing strategies.

In the computerized time where organizations are going to, advanced promoting devices and methods give entrepreneurs the sole opportunities for contest, endurance and even business development..

Keywords: E-commerce, Digital Marketing, Search Engine Optimization (SEO), Search Engine Marketing (SEM), Competitor Research, Social Media Marketing.

\section{INTRODUCTION}

The world has been digitized.The requirement for individuals to keep digitalization is the need of the day. Publicizing and limited time exercises are done through the computerized method of distributing the original copies, hoardings, and presentations with the assistance of electronic gadgets. Web-based media is advancing the patterns of computerized showcasing. Especially, the people who are going into web based business; they are using advanced showcasing extremely high contrasted with different kinds of organizations. The pattern and conditions of advanced advertising are shifted every once in a while, changing innovation and its updates, augmentations of business exercises, hierarchical turn of events, and market stabilities.

The e commerce business moving is top-finished to another period of digitized showcasing framework which having computerized show-room, advanced labels of cost with offering limits, advanced exchange of deals with deals return while clients' disappointed on acquisition of labor and products, computerized client relationship the board with legitimate data set, computerized publicizing through the web-based media, and advanced correspondence by quick reactions to both the vender and buyer.

\section{Digital Marketing}

Promoting, Advertising or Marketing any type of Product, Goods or Services using any type of Digital or Electronic Medium is known as Digital Marketing..

Digital Marketing is the term used for the targeted, measurable, and interactive marketing of products or services using digital technologies to succeed in the viewers, turn them into customers, and retain them.

Online marketing \& internet marketing is a part of digital marketing, not whole of digital marketing. Digital marketing includes many aspects of communication and is not limited to mobile phones or the internet.

Digital marketers leverage digital channels like search engines, social media, emails and websites to assist their clients connect with existing and potential customers. They then proceed to gather data gathered from these digital channels (such as checking the amount of impressions or likes on Instagram) and Google Analytics to plan their marketing strategy. 

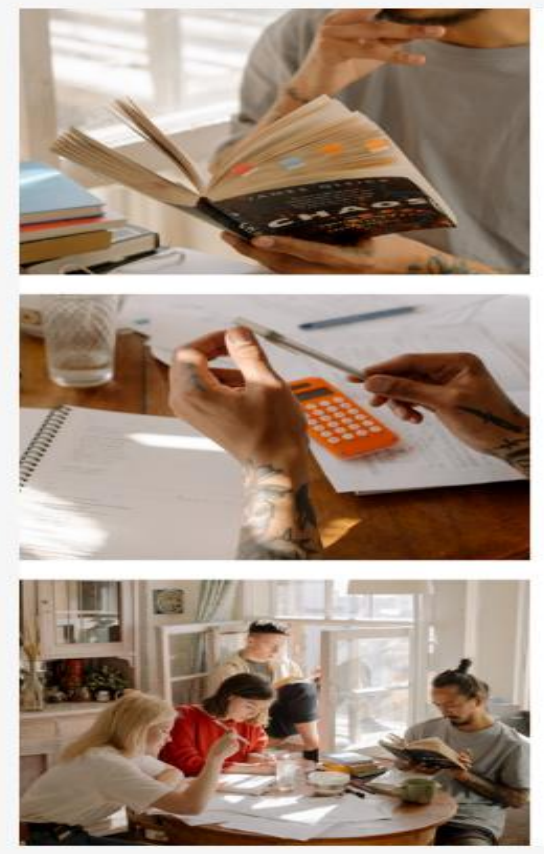

\section{Research \& Analysis}

Research about your Audience \& Analyzing your Competitor's Marketing Strategy will help you understand the Promotional Opportunities.

\section{Planning a Roadmap}

On basis of the Audience Research \& Competitor's Marketing Strategy, Identify the platforms and right product to promote. Choosing the right audience is Important.

\section{Executing \& Implementing}

Creating a Paid Campaign targeting the Right Audience at Identified Location with Decision making age group. Optimizing the campaign to get desired results.

\section{Market Research}

Market research could be a process to spot "what your consumer needs? " in the real market.

Market research also helps in identifying new markets or opportunities for any type of products or services.

Market research also helps to spot the proper platform to settle on to promote your product, service or business to the right targeted audience.

Market research is that the most significant process, which can facilitate your to create a successful digital marketing strategy.

\section{Competitor Research}

Competitor research may be a process to spot "what your competitors are doing? " within the real market.

Competitor research also helps to identify the problems in the current market that consumers are facing while dealing with your competitors. make sure our product solves it.

Digital marketing has such a lot of options and methods related to it, business people can get creative and experiment with a range of promoting tactics on a budget.

With digital marketing, they will also use tools, sort of analytics dashboards to observe the success and ROI of their campaigns quite as they might with traditional promotional content like a billboard or print ad.

\section{Content Development On Digital Marketing}

In the start of 2000 millenniums. Advanced and online business have changed the manner in which brands and organizations use innovation for advertising. As computerized stages turned out to be progressively fused into showcasing plans and regular day to day existence (Nielsen, 2016). furthermore, as individuals progressively utilize advanced gadgets as opposed to visiting actual shops (Nielsen, 2016), computerized showcasing efforts have become predominant, utilizing blends of Search Engine Optimization (SEO), Search Engine Marketing (SEM), content Marketing, powerhouse promoting, content mechanization, crusade showcasing, information driven advertising, internet business advertising, 
web-based media showcasing, web-based media improvement, email direct showcasing, show publicizing, digital books, and optical circles and games have become typical. Advanced showcasing stretches out to non-Internet stations that give computerized media, like TV, cell phones (SMS and MMS), callback, and on-hold versatile ringtones. The expansion to non Internet channels separates advanced advertising from web based promoting.

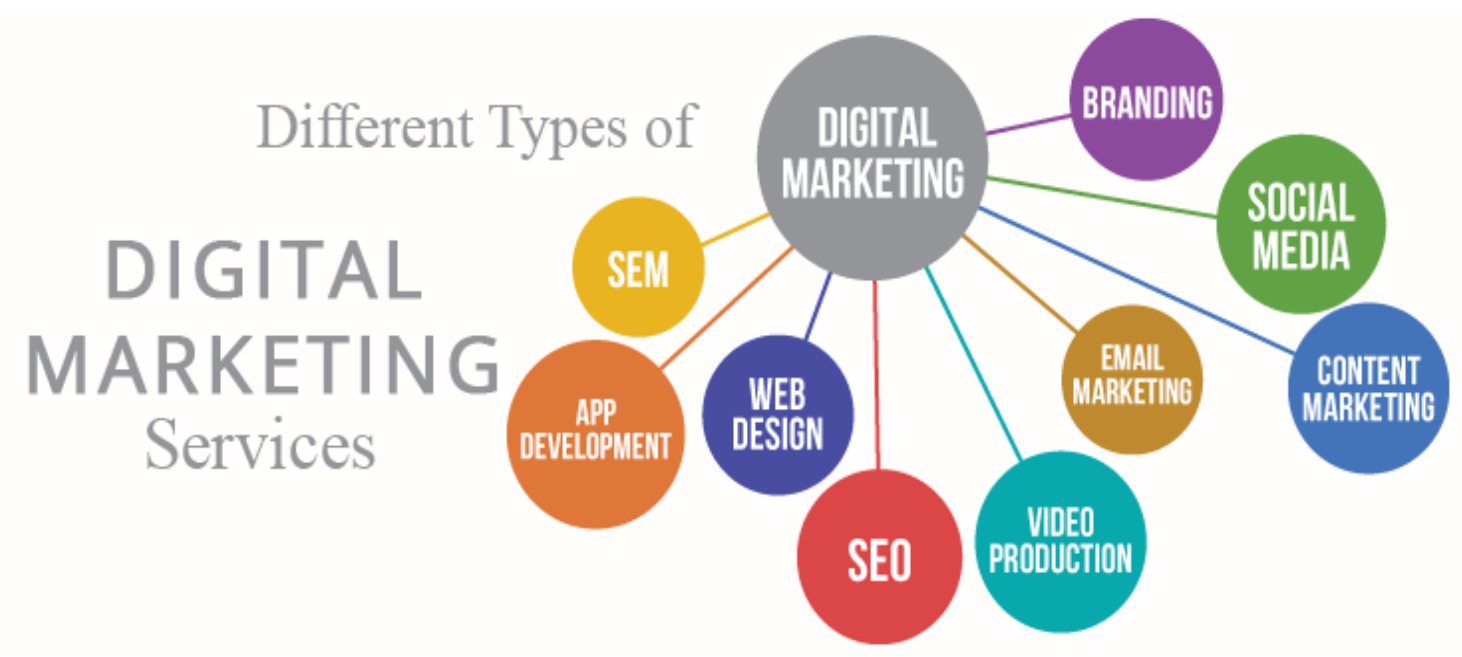

\section{Types of Digital Marketing Platforms}

\section{1) Search Engine}

Search engine is a program that looks for and recognizes things in an information base that relate to correspond to keywords or characters specified by the user.

\section{2) Social Media}

Social media is a collective term for websites and applications which focus on communication, community-based input, inter04. influencer marketing influencer marketing involves a brand collaborating with an online influencer to market one of its products or services.

03) Affiliate Marketing

Affiliate marketing is the most common way of earning a commission by promoting other people's (or company's) products.

\section{4) Influencer Marketing}

Influencer advertising entails a manufacturer working collectively with an on-line influencer to market one of its merchandise or services.

\section{RESEARCH METHODOLOGY}

Auxiliary statistics is gathered from environmentally friendly contemporary springs in numerous recommendation brochures and annals. Secondary data was once accumulated from the periodicals, web sites. To meet goals, the investigation utilized subjective research. The clear investigation stood whole by way of audit of existing writing that aided in approval and withdrawal of the tremendous elements and issues. Information used to be gathered from auxiliary bases. "'Auxiliary sources stood periodicals, sites, records, administrative middle officials, barring friends' information.""

In the examination I have gathered records from auxiliary sources.

\section{RESULTS AND DISCUSSION}

\section{The Growth of Digital Marketing}

The scope of digital selling in 2020 and 2021 has seen forceful growth. When we consider the key indicators of success in marketing, the primary thing we expect of is the number of individuals reached through marketing practices. The internet's stabbing has reached outstanding numbers. Looking at India, it's the 2nd largest number of internet users within the world. 
By 2023, the amount of active Indian internet users will grow to almost 666 million. Thus, this means that a bigger share of individuals are shifting online and hence it makes complete sense to start out marketing online.

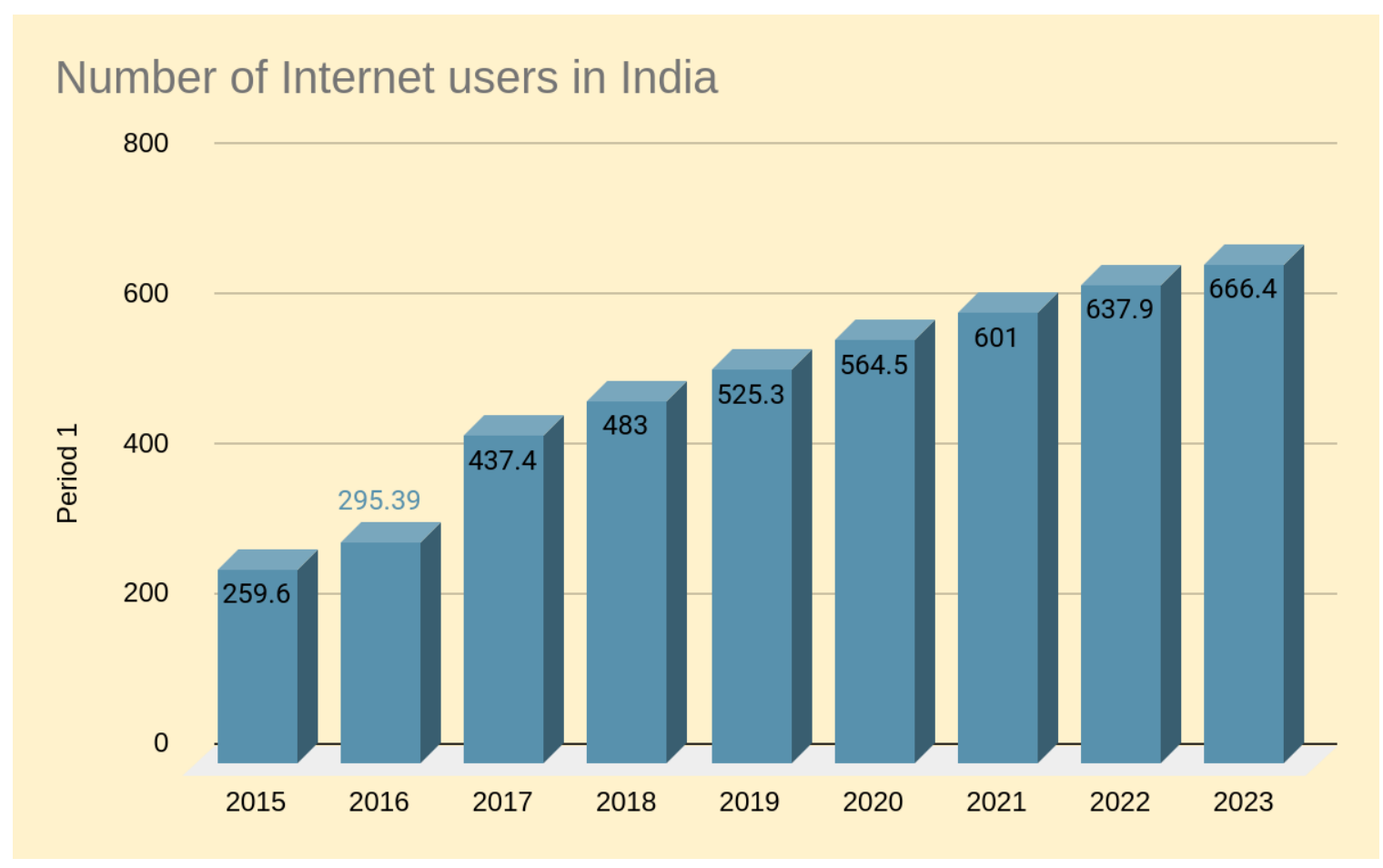

\section{Scope of Digital Marketing in the Future}

As mentioned above, the expansion of digital marketing has been very impressive and therefore the numbers show that the expansion goes to ascertain an upward trend within the future. Simply put, the longer term of digital marketing looks secure and bright.

More and more opportunities will keep coming in and thus, being creative, innovative, and updated with the newest trends is the fundamentals of each digital marketer.

The growth that we've witnessed on the web over the years, especially since covid, is here to remain . People are adapting to the new normal and actually are now very comfortable with completing matters online, be it for shopping, ordering meals or medicines, or even carrying out banking transactions online.

Hence, to cater to these new-formed needs of the consumers, digital advertising is extraordinarily essential.

In addition to this, an important aspect to consider is that the future generation will be a section of the already digital world and will be accustomed to the whole lot being online. So to be ready to deliver to those future consumers, companies must make digital marketing efforts starting today.

\section{Objectives of the research}

1) The main purpose of this paper is to acknowledge the usefulness of digital marketing within the competitive market.

2) Collect and implement the feedback provided by the buyer within the right way.

3) Provide a transparent and good service to the buyer before and after purchase.

4) To review the impact of digital marketing on consumers' purchase.

5) The complete description needs to be provided about the product to the online shoppers.

\section{Review of Literature}

As indicated by Dasgupta, and Ghatge (2015), Because of the simple consolidation and similarity of the Internet with a few kinds of advanced gadgets like tablets, cell phones, watches, etc, its remainders are at the focal piece of computerized advertising. More likely than not, the main advancement of the 20th century is the Internet, which has changed the scope of advertising. In addition, the Internet has shown up through a device supporting the diverse reason for promoting, flow, and association building deals. These days items are put, promoted, coursed and purchased with the assistance of the 
web. The blended system of customary promotion is changed by the Internet. Furthermore, it permits the sales rep to promote added assortment of mass adjusted products. To look at the cost among existing products, work with the Internet is prominent. Moreover, a unique method of dissemination which is convenient, quick and simple, is added by the Internet. Promoting has drilled the model change whereby conversations have involved the spot of lucrative messages, just as customers have ended up being narrators. These days, Salesperson and advertisers are rehearsing different strategies for showcasing for carrying out the technique of computerized promoting like "Website design enhancement" (Search Engine Optimization), "SEM" (Search Engine Marketing), then, at that point "PPC" (Pay-per-snap) and others.

\section{CONCLUSION}

Thus it will be fruitful to assert that almost everyone is continuously linked with everybody as well as the whole thing. Common people are nowadays enabled to access the internet in their day to day life with the help of the innovations of mobile together with low-cost data. With respect to the present time, Businesses must have the presence of the digital medium, or else they are getting to be digital. What works and what doesn't is verbalized by the precise intermingling of frame and appropriateness, similar to the Experience of the Consumer.Appropriately, no plug is there as far as computerized advertising in India. As it is an advancement of the business in virtual situations so the best methodology utilized by organizations includes is to focus on the clients when they are online before their PCs or smartphones and urge them to attempt their items. That is the cause in the continuing occasions organizations center has consistently been around the procedures of digital marketing. Various organizations have utilized over three methodologies that are email marketing, social marketing, and mobile marketing to its greatest use and that is the reason marketing has technologically advanced and organizations actualizing viable business plans are so operative. Subsequently, it can be said by one that the strategies of Digital Marketing along with the achievement of business both go as being one. If business needs to get benefits then they should fill in according to the systems of Digital Marketing in India as everybody and the entire thing is intermittently related via approaches for digitalization.

\section{REFERENCES}

D. Agrawal, R. P. Agrawal, J. B. Singh and S. P. Tripathi, "E-commerce: True Indian Picture”, Journal of Advances in IT, vol. 3, no. 4, (2012), pp. 250-257.

N. Edwards, S. Handcock and J. Mullen,

"Electronic commerce: reality bytes", Supply Management, vol. 3, no. 8, (1997), pp. 32-34.

https://iide.co/blog/scope-of-digital-marketing/ - Internet Users data

D. C. Fain and J. O. Pedersen, "Sponsored Search: A Brief History", Bulletin of the American Society for Information Science and Technology, vol. 32 , no. 2, (2006), pp. 12-13.

https://datareportal.com/reports/digital-2020-india

R. Rastogi, "Country Report on E-Commerce (India, Ministry of Communications and Information Technology", Department of Information Technology, Office of the Controller of Certifying Authorities), pp. 133-146.

R. R. Ruckman, http://www.imgrind.com/10-advantages-of-internet-marketing/10 Advantages Of Internet Marketing, (2012) January 19.

https://www.statista.com/statistics/617136/digital-population-worldwide/

https://en.wikipedia.org/wiki/List_of_countries_by_number_of_Internet_users

https://www.encora.com/insights/role-of-digital-marketing

https://sproutsocial.com/insights/social-media-marketing-strategy/

https://blog.hubspot.com/marketing/ecommerce-marketing

https://www.bigcommerce.com/blog/ecommerce-marketing/

https://www.smartinsights.com/ecommerce/ecommerce-strategy/optimize-your-e-commerce-digital-marketing-strategy/ 